\title{
Faktor Risiko yang Memengaruhi Kolonisasi Mikroflora Saluran Cerna Neonatus Kurang Bulan dengan Enterokolitis Nekrotikans
}

\author{
Ratno Juniarto Marulitua Sidauruk, Idham Amir, Muzal Kadim, Mardjanis Said \\ Departemen Ilmu Kesehatan Anak Fakultas Kedokteran Universitas Indonesia-RSCM, Jakarta
}

\begin{abstract}
Latar belakang. Insiden enterokolitis nekrotikans (necrotizing enterocolitis, NEC) sekitar 1 per 1000 kelahiran hidup, dan $\mathbf{9 0 \%}$ terjadi pada neonatus kurang bulan (NKB). Patofisiologi NEC belum jelas, salah satu penyebabnya diduga akibat kolonisasi mikroflora yang abnormal. Faktor risiko yang dapat memengaruhi kolonisasi mikroflora saluran cerna, yaitu cara persalinan, lama pemakaian antibiotik, dan tipe nutrisi.

Tujuan. Mengetahui proporsi mikroflora pada NKB dengan dan tanpa NEC serta faktor risiko yang memengaruhi kolonisasi mikroflora saluran cerna NKB dengan NEC.

Metode. Penelitian potong lintang dilakukan pada NKB dengan NEC derajat II selama periode MaretOktober 2012. Dilakukan pemeriksaan tinja dengan quantitative realtime PCR untuk mendeteksi kolonisasi mikroflora B. lactis, L. acidophilus, Bifidobacterium sp., Lactobacillus sp., E. coli, C. difficile, dan K. pneumoniae.

Hasil. Tigapuluh subjek NKB dengan NEC dan 10 subjek NKB tanpa NEC diikutsertakan dalam penelitian. Pada subjek NEC, $K$. pneumoniae terdeteksi dengan median proporsi 15,2\%, Bifidobacterium sp. 13,4\%, E. coli $1,0 \%$, Lactobacillus sp. $0,1 \%$, B. lactis $0,0 \%$, C. difficile $0,0 \%$, dan L. acidophilus $0,00 \%(0,0-1,8 \%)$. Pada subjek tanpa NEC, Bifidobacterium sp. terdeteksi dengan proporsi $29,5 \%, K$. pneumoniae $0,9 \%, E$. coli $0,3 \%$, Lactobacillus sp. 2,3\%, B. lactis $0,0 \%$, C. difficile 0,0\%, sedang L. acidophilus tidak terdeteksi. Tidak ditemukan perbedaan proporsi ketujuh mikroflora yang bermakna secara statistik pada NKB dengan NEC berdasarkan cara persalinan, lama mendapat antibiotik, dan tipe nutrisi ( $\mathrm{p}>0,05)$.

Kesimpulan. K.pneumoniae memiliki proporsi terbesar pada subjek NEC, sedangkan Bifidobacterium sp. pada subjek tanpa NEC. Cara persalinan, lama pemakaian antibiotik, dan tipe nutrisi tidak memengaruhi proporsi kolonisasi mikroflora saluran cerna subjek NEC.
\end{abstract}

Sari Pediatri 2014;15(6):353-60.

Kata kunci: neonatus kurangbulan, enterokolitis nekrotikans, kolonisasi mikroflora

Alamat korespondensi:

Dr. Ratno Juniarto Marulitua Sidauruk, Sp.A. Jl. Gandaria Raya RT 006/ RT 002 Jagakarsa. Telp. (021) 78885676. E-mail: sidbers@gmail.com

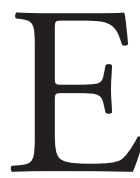

nterokolitis nekrotikans (necrotizing enterocolitis, NEC) merupakan sindrom multifaktorial nekrosis iskemik intestinal akut dan menjadi salah satu penyebab 
kegawatan gastrointestinal pada neonatus. Kemajuan unit perawatan neonatus menyebabkan NKB yang mampu bertahan hidup bertambah sehingga insiden NEC juga bertambah. Insiden NEC adalah 1 per 1000 kelahiran hidup (5\%-10\%), dan lebih dari $90 \%$ terjadi pada NKB. ${ }^{1,2}$ Selama tahun 2009, di Divisi Perinatologi Departemen Ilmu Kesehatan Anak (IKA) Rumah Sakit Cipto Mangunkusumo (RSCM) terdapat 31 kasus NEC dari sekitar 737 kelahiran kurang bulan.

Angka kematian akibat NEC berkisar antara 15\%-30\%, lebih tinggi pada bayi dengan usia gestasi yang lebih muda, dan merupakan salah satu penyebab kematian terbanyak di neonatal intensive care unit (NICU). Angka kematian dapat mencapai $40 \%$ pada neonatus yang mengalami NEC dengan perforasi dan membutuhkan intervensi bedah. ${ }^{1}$ Neonatus dengan NEC juga lebih sering mengalami infeksi nosokomial, asupan nutrisi yang tidak adekuat, pertumbuhan yang lambat, insiden displasia bronkopulmonal dan retinopati prematuritas lebih tinggi, serta membutuhkan waktu perawatan intensif yang lama. ${ }^{3}$

Penyebab NEC belum diketahui secara jelas sampai saat ini, tetapi beberapa hal yang diduga menjadi penyebab, yaitu respon hipereaktivitas sistem imun, iskemik, infeksi, pengenalan makanan enteral, kolonisasi mikroflora yang abnormal, ataupun respon terhadap translokasi mikroflora pada saluran cerna. ${ }^{4}$ Imaturitas sel epitel intestinal dan mekanisme respons imun traktus gastrointestinal pada NKB memudahkan terjadinya kerusakan sawar intestinal dan kolonisasi abnormal mikroflora. ${ }^{4}$ Paparan terhadap beragam bakteri nosokomial di NICU dan ketidakmampuan respon sistem imun terhadap kolonisasi mikroflora abnormal memudahkan terjadi NEC pada NKB. ${ }^{5}$

Beberapa penelitian menunjukkan bahwa kolonisasi abnormal saluran cerna berkaitan erat dengan NEC, tetapi semuanya memperlihatkan bahwa tidak ada mikroflora patogen tunggal yang secara konsisten berkaitan dengan perkembangan terjadinya NEC. ${ }^{6}$ Mikroflora Clostridium sp., Klebsiella pneumoniae, E. coli, Enterobacter, dan Staphylococci banyak ditemukan pada saluran cerna NKB dengan NEC. Translokasi mikroflora patogen akibat imaturitas sawar intestinal juga dipengaruhi diversitas mikroflora pada saluran cerna. Studi yang menggunakan pemeriksaan mikrobiologi molekular menunjukkan bahwa pada pasien NEC terdapat low diversity mikroflora dibandingkan dengan pasien tanpa NEC sebagai akibat penggunaan antibiotik yang lama. Low diversity mikroflora ini dapat meningkatkan risiko translokasi mikroflora patogen sehingga memudahkan terjadinya NEC. ${ }^{7}$

Pemberian ASI telah diketahui dapat menurunkan insiden NEC dengan menurunkan kolonisasi bakteri patogen, membantu pertumbuhan mikroflora nonpatogen, maturasi sawar intestinal, dan memperbaiki respon pro-inflamasi. ${ }^{8,9}$ Hunter $\mathrm{dkk}^{6}$ mengemukakan bahwa ASI dapat menstimulasi mikroflora saluran cerna yang didominasi oleh Bifidobacteria sedang susu formula dapat mempromosikan mikroflora yang lebih beragam, didominasi oleh Enterobacteriaceae, Bacteroides, Clostridia, serta lebih sedikit Bifidobacteria. Terdapat 3 studi pada bayi kurang bulan dan cukup bulan yang mengemukakan bahwa tidak ada perbedaan kolonisasi Bifidobacteria pada kelompok yang diberi ASI maupun susu formula, tetapi secara konsisten menunjukkan kecenderungan prevalensi Clostridia yang rendah pada kelompok ASI. ${ }^{10,11,12}$

Bayi yang dilahirkan secara bedah kaisar mengalami penundaan kolonisasi mikroflora saluran cerna. Kolonisasi awal pada bayi yang lahir bedah kaisar tersebut didominasi oleh bakteri lingkungan seperti Clostridia, E. coli, dan Streptococci. ${ }^{13}$ Studi oleh Penders $\mathrm{dkk}^{14}$ menyebutkan bahwa bayi yang lahir secara bedah kaisar mempunyai jumlah Bifidobacterium dan Bacteroides yang lebih sedikit dan lebih sering terkolonisasi oleh $C$. diffcile dibanding bayi yang lahir per vaginam. Sebaliknya, terdapat juga beberapa studi yang menyatakan bahwa tidak ada perbedaan mikroflora baik pada bayi yang lahir per vaginam maupun bedah kaisar. ${ }^{10,15,16}$

Berbagai interaksi antara mikroflora normal dan pejamu dapat menghambat pertumbuhan bakteri patogen. Mikroflora normal seperti Bifidobacterium $s p$. dan Lactobacillus sp. yang juga dikenal sebagai probiotik telah diketahui dapat mencegah NEC dengan mengatur keseimbangan antara mikroflora komensal dan patogen pada saluran cerna. Metaanalisis terhadap beberapa uji klinis acak tersamar ganda menyebutkan bahwa pemberian probiotik pada NKB dapat menurunkan insidens NEC (menurunkan risiko relatif NEC sebesar 0,35 dan mortalitas sebesar $0,41)$. Hasil terbaik dengan memberikan dua atau lebih spesies dan atau kombinasi Bifidobacterium sp. dan Lactobacillus acidophilus. ${ }^{17}$ 


\section{Metode}

Penelitian potong lintang dengan melakukan pemeriksaan quantitative real time PCR. Penelitian dilakukan di Divisi Perinatologi Departemen IKA RSCM, Rumah Sakit Umum Pusat (RSUP) Fatmawati, Rumah Sakit Umum Daerah (RSUD) Koja, dan Rumah Sakit Anak Bunda (RSAB) Harapan Kita. Sampel penelitian diambil secara consecutive sampling. Subjek penelitian adalah NKB yang mengalami NEC derajat II berdasarkan kriteria Bell's. ${ }^{18}$ Untuk mengetahui gambaran kolonisasi mikroflora pada saluran cerna NKB tanpa NEC, peneliti memeriksa tinja 10 subjek. Neonatus dengan suatu sindrom atau kelainan kongenital, kelainan anatomis saluran cerna dieksklusi dalam penelitian ini.

- Kolonisasi mikroflora saluran cerna adalah kolonisasi mikroorganisme yang hidup di saluran cerna, antara lain B. lactis, L. acidophilus, Bifidobacterium sp., Lactobacillus sp, E. coli, C. difficile, dan K. pneumoniae. Kolonisasi mikroflora tersebut dinyatakan dalam proporsi terhadap jumlah seluruh mikroflora yang terdeteksi oleh pemeriksaan quantitative real time PCR.

- Neonatus kurang bulan adalah bayi dengan usia gestasi $<37$ minggu berdasarkan skor Ballard. ${ }^{19}$ Skor Ballard akan dinilai oleh dokter anak.

- Enterokolitis nekrotikans adalah penyakit nekrosis akut intestinal yang patofisiologinya belum diketahui secara pasti, terdiri atas tiga derajat menurut kriteria Bell's. ${ }^{18}$ Sampel penelitian ini merupakan NKB dengan NEC minimal derajat 2 berdasarkan kriteria tersebut.

- Neonatus kurang bukan tanpa NEC adalah neonatus yang tidak mengalami NEC dengan usia gestasi dan usia kehidupan yang sama dengan NKB dengan NEC.

- Subjek ASI adalah subjek yang hanya mendapat asupan nutrisi berupa ASI.

- Subjek Non-ASI meliputi subjek yang mendapat asupan nutrisi berupa susu formula, campuran ASI dan susu formula, maupun subjek yang belum minum.

- Lama pemakaian antibiotik pada neonatus adalah durasi sejak subjek mulai mendapat antibiotik hingga mengalami NEC. Lama pemakaian antibiotik dibagi menjadi 2 kelompok yaitu $\leq 1$ minggu dan $>1$ minggu.

- Kelainan kongenital saluran cerna meliputi atresia, striktur atau kelainan posisi saluran cerna yang membutuhkan tindakan operasi untuk memperbaiki kelainan tersebut.

- Quantitative real-time PCR adalah suatu pemeriksaan laboratoris yang berdasarkan PCR, digunakan untuk amplifikasi dan kuantifikasi secara simultan molekul DNA target. Hasil dapat berupa jumlah kopi absolut ataupun relatif.

Data diolah dengan menggunakan program SPSS versi 17. Persetujuan penelitian diberikan oleh Komisi Etik Penelitian Fakultas Kedokteran Universitas Indonesia. Persetujuan mengikuti penelitian diberikan oleh orangtua setelah diberikan penjelasan mengenai tujuan, prosedur, manfaat, serta risiko penelitian.

\section{Hasil}

Selama kurun waktu penelitian didapatkan 34 subjek NKB dengan NEC yang memenuhi kriteria inklusi. Dua subjek meninggal sebelum sampel tinja dapat dikumpulkan. Sampel tinja 2 subjek lainnya tidak mencukupi untuk dilakukan analisis. Alur pengambilan sampel tertera pada Gambar 1.

Karakteristik subjek penelitian tertera pada Tabel 1. Subjek NEC terdiri dari 18 laki-laki dan 12 perempuan. Median usia gestasi subjek NEC adalah 32 minggu (27-35 minggu). Median usia pengumpulan tinja subjek NEC adalah 11 hari (5-64 hari). Subjek NEC yang meninggal memiliki berat lahir $<1000$ gram sejumlah 4 subjek, 2 subjek lainnya memiliki berat lahir 1000-1499 gram (median 922 gram, 6501060 gram). Subjek tanpa NEC terdiri dari 6 laki-laki

Neonatus kurang bulan dengan NEC ( $\mathrm{n}=34)$



Hasil dan analisis $(\mathrm{n}=30)$

Gambar 1. Alur pengambilan subjek penelitian 
Tabel 1. Karakteristik dasar subjek penelitian

\begin{tabular}{lcc}
\hline & \multicolumn{2}{c}{ Subjek } \\
\cline { 2 - 3 } Karakteristik & $\begin{array}{c}\text { NEC } \\
(\mathrm{n}=30)\end{array}$ & $\begin{array}{c}\text { Tanpa } \\
\text { NEC } \\
(\mathrm{n}=10)\end{array}$ \\
\hline Jenis kelamin & & \\
$\quad$ Laki-laki & & \\
$\quad$ Perempuan & $18 / 30$ & $6 / 10$ \\
Usia gestasi & $12 / 30$ & $4 / 10$ \\
Median (rentang)/minggu & $32(27-35)$ & $32(26-35)$ \\
Usia pengumpulan tinja & & \\
Median (rentang)/hari & $11(5-64)$ & $15,5(9-27)$ \\
Cara persalinan & & \\
$\quad$ Spontan & $13 / 30$ & $6 / 10$ \\
$\quad$ Bedah kaisar & $17 / 30$ & $4 / 10$ \\
Tipe nutrisi & & \\
$\quad$ ASI & $11 / 30$ & $5 / 10$ \\
$\quad$ Non ASI & $19 / 30$ & $5 / 10$ \\
Lama pemakaian antibiotik & & \\
(minggu) & & \\
$\quad \leq 1$ & & \\
$\quad>1$ & $7 / 30$ & $8 / 10$ \\
Berat lahir (gram) & $23 / 30$ & $2 / 10$ \\
$\quad<1000$ & & \\
$\quad 1000-1499$ & $5 / 30$ & $0 / 10$ \\
$\quad 1500-1999$ & $15 / 30$ & $4 / 10$ \\
Luaran & $10 / 30$ & $6 / 10$ \\
$\quad$ Hidup & & \\
$\quad$ Meninggal & $24 / 30$ & $10 / 10$ \\
$\quad$ & $6 / 30$ & $0 / 10$ \\
\hline
\end{tabular}

dan 4 perempuan. Median usia gestasi subjek tanpa NEC yaitu 32 minggu (26-35 minggu). Median usia pengumpulan tinja subjek tanpa NEC yaitu 15,5 hari (9-27 hari).

Jumlah mikroflora yang dinyatakan sebagai proporsi terhadap total mikroflora yang terdeteksi pada sampel tinja subjek NEC dan tanpa NEC tertera pada Tabel 2. Pada subjek NEC, $K$. pneumoniae memiliki proporsi paling banyak dengan median $15,2 \%(0,0-$ $70,2 \%)$ dan jumlah absolut/100 mg tinja berkisar $0-3,8 \times 10^{6}$. Mikroflora B. lactis dan L. acidophilus memiliki proporsi paling sedikit dengan median masing-masing $0,0 \%(0,0-0,2 \%)$ dan $0,0 \%(0,00-$ $1,8 \%)$. Pada subjek tanpa NEC, Bifidobacterium species memiliki proporsi terbesar dengan rerata $29,5 \%$ $(13,3 \%)$ dan jumlah absolut/100 mg tinja berkisar $5,4 \times 10^{4}$ hingga $4,3 \times 10^{6}$. Mikroflora $C$. difficile memiliki proporsi paling sedikit dengan median $0,0 \%$ (0,0-0,0\%) dan rentang jumlah absolut/100 mg tinja berkisar $0,2 \times 10^{2}-0,4 \times 10^{2}$

Jumlah mikroflora yang dinyatakan sebagai proporsi terhadap total mikroflora yang terdeteksi pada sampel tinja subjek NEC berdasarkan cara persalinan tertera pada Tabel 3. Uji statistik pada kelompok subjek NEC berdasarkan cara persalinan baik secara spontan maupun bedah kaisar tidak menunjukkan perbedaan proporsi mikroflora Bifidobacterium sp., $K$. pneumoniae, B. lactis, Lactobacillus sp., L. acidophilus,

Tabel 2. Proporsi mikroflora terhadap total bakteri saluran cerna NKB dengan dan tanpa NEC

\begin{tabular}{lcc}
\hline \multirow{2}{*}{ Mikroflora } & \multicolumn{2}{c}{ Rentang jumlah absolut/100 mg tinja } \\
\cline { 2 - 3 } Bifidobacterium sp. & Subjek NEC & Subjek tanpa NEC \\
\cline { 2 - 3 } B. lactis & $13,4(1,8-50.9)^{* *}$ & $29,5(13,3)^{*}$ \\
Lactobacillus sp. & $1,7 \times 10^{4}-2,8 \times 10^{6}$ & $5,40 \times 10^{4}-4,3 \times 10^{6}$ \\
& $0,0(0,0-0,2)^{* *}$ & $0,0(0,0-0,01)^{* *}$ \\
L. acidophilus & $0-9,0 \times 10^{3}$ & $0,4 \times 10^{2}-3,2 \times 10^{2}$ \\
& $0,1(0,0-19,4)^{* *}$ & $2,3(2,3)^{*}$ \\
E. coli & $0-2,2 \times 10^{6}$ & $1,4 \times 10^{4}-7,9 \times 10^{5}$ \\
C. difficile & $0,0(0,0-1,8)^{* *}$ & $0,0(0,0-0,0)^{* *}$ \\
K. pneumoniae & $0-2,0 \times 10^{5}$ & $0-0$ \\
& $1,4(0,0-43,9)^{* *}$ & $0,3(0,0-1,8)^{* *}$ \\
& $0-1,3 \times 10^{6}$ & $1,5 \times 10^{2}-5,1 \times 10^{4}$ \\
& $0,0(0,0-11,6)^{* *}$ & $0,0(0,0-0,0)^{* *}$ \\
\hline
\end{tabular}

Rerata $(\mathrm{SD})^{*} /$ median $(/ \text { rentang })^{* *} \%$ 
E. coli, maupun C. difficile ( $\mathrm{p}>0,05)$.

Jumlah mikroflora yang dinyatakan sebagai proporsi terhadap total mikroflora yang terdeteksi pada sampel tinja subjek NEC berdasarkan lama pemakaian antibiotik tertera pada Tabel 4. Uji bivariat Mann Whitney pada kelompok subjek NEC berdasarkan lama pemberian antibiotik tidak menunjukkan perbedaan proporsi Bifidobacterium sp, B. lactis, Lactobacillus sp., $L$. acidophilus, E. coli, $C$. diffcile, dan $K$. pneumoniae (semuanya dengan $\mathrm{p}>0,05$ ) pada kelompok lama pemakaian antibiotik $\leq 1$ minggu maupun $>1$ minggu.

Jumlah mikroflora yang dinyatakan sebagai proporsi terhadap total mikroflora yang terdeteksi pada sampel tinja subjek NEC berdasarkan tipe nutrisi

Tabel 3. Proporsi mikroflora terhadap total bakteri saluran cerna NKB dengan NEC berdasarkan cara persalinan

\begin{tabular}{|c|c|c|c|}
\hline \multirow{2}{*}{ Mikroflora } & \multicolumn{2}{|c|}{ Cara persalinan } & \multirow[b]{2}{*}{$\mathrm{p}$} \\
\hline & Spontan $(\mathrm{n}=13)$ & Bedah kaisar(17) & \\
\hline Bifidobacterium sp. ${ }^{\circ}$ & $16,4(6,7-50,9)$ & $9,7(1,8-41,9)$ & $0,300^{*}$ \\
\hline Bifidobacterium lactis $^{0}$ & $0,0(0,0-0,2)$ & $0,0(0,0-0,1)$ & $0,183^{*}$ \\
\hline Lactobacillus sp. ${ }^{\circ}$ & $0,1(0,0-6,3)$ & $0,2(0,00-19.40)$ & $0,300^{*}$ \\
\hline Lactobacillus acidophilus $^{0}$ & $0,0(0,0-0,0)$ & $0,0(0,0-1,8)$ & $0,592^{*}$ \\
\hline E. coli ${ }^{0}$ & $4,8(0,0-19,3)$ & $0,4(0,0-43,9)$ & $0,967^{*}$ \\
\hline C. difficile ${ }^{0}$ & $0,0(0,0-11,1)$ & $0,0(0,0-11,1)$ & $1,000^{*}$ \\
\hline K. pneumoniae ${ }^{o o}$ & $27,7(25,2)$ & $12,5(9,6)$ & $0,057^{* *}$ \\
\hline
\end{tabular}

* Uji Mann Whitney ${ }^{o}$ Median (rentang) \%

** Uji T-independent ${ }^{\circ 0}$ Rerata (SD)\%

Tabel 4. Proporsi mikroflora terhadap total bakteri saluran cerna NKB dengan NEC berdasarkan lama pemberian antibiotik

\begin{tabular}{|c|c|c|c|}
\hline \multirow{2}{*}{ Mikroflora } & \multicolumn{2}{|c|}{ Lama pemberian antibiotik } & \multirow{2}{*}{$\mathrm{p}$} \\
\hline & $\leq 1 \operatorname{minggu}(\mathrm{n}=7)$ & $>1$ minggu $(n=23)$ & \\
\hline Bifidobacterium sp. ${ }^{o}$ & $22,9(3,9-41,9)$ & $12,4(1,8-50,9)$ & 0,360 \\
\hline Bifidobacterium lactis $^{0}$ & $0,0(0,0-0,0)$ & $0,0(0,0-0,2)$ & 0,131 \\
\hline Lactobacillus sp. ${ }^{\circ}$ & $0,6(0,0-3,8)$ & $0,1(0,0-19,4)$ & 0,360 \\
\hline Lactobacillus acidophilus ${ }^{0}$ & $0,0(0,0-0,0)$ & $0,0(0,0-1,8)$ & 0,737 \\
\hline E. coli $^{0}$ & $0,4(0,0-22,6)$ & $1,6(0,0-43,9)$ & 0,848 \\
\hline C. difficile ${ }^{0}$ & $0,0(0,0-0,0)$ & $0,0(0,0-11,6)$ & 0,598 \\
\hline K. pneumoniae ${ }^{o}$ & $6,5(0,0-23,7)$ & $15,6(0,0-70,1)$ & 0,266 \\
\hline
\end{tabular}

${ }^{o}$ Median (rentang) \%

Tabel 5. Proporsi mikroflora terhadap total bakteri saluran cerna NKB dengan NEC berdasarkan tipe nutrisi

\begin{tabular}{|c|c|c|c|}
\hline \multirow{2}{*}{ Mikroflora } & \multicolumn{2}{|c|}{ Tipe nutrisi } & \multirow[b]{2}{*}{$\mathrm{p}$} \\
\hline & ASI $(n=11)$ & Non-ASI $(n=19)$ & \\
\hline Bifidobacterium sp. ${ }^{\circ}$ & $17,9(2,6-35,9)$ & $9,9(1,8-50,9)$ & 0,582 \\
\hline Bifidobacterium lactis $^{0}$ & $0,0(0,0-0,0)$ & $0,0(0,0-0,2)$ & 0,672 \\
\hline Lactobacillus sp. ${ }^{\circ}$ & $0,2(0,0-19,4)$ & $0,0(0,0-6,3)$ & 0,395 \\
\hline Lactobacillus acidophilus $^{0}$ & $0,0(0,0-1,8)$ & $0,0(0,0-0,0)$ & 0,866 \\
\hline E. coli ${ }^{0}$ & $0,5(0,0-22,5)$ & $1,6(0,0-43,9)$ & 0,899 \\
\hline C. difficile ${ }^{0}$ & $0,0(0,0-11,6)$ & $0,0(0,0-11,1)$ & 0,767 \\
\hline Klebsiella pneumoniae ${ }^{0}$ & $15,2(0,0-70,2)$ & $16,8(0,0-56,5)$ & 0,735 \\
\hline
\end{tabular}

${ }^{o}$ Median (rentang) \% 
tertera pada Tabel 5. Uji bivariat Mann Whitney pada kelompok subjek NEC berdasarkan tipe nutrisi tidak menunjukkan perbedaan proporsi mikroflora Bifidobacterium sp., B. lactis, Lactobacillus sp., L. acidophilus, E. coli, $C$. diffcile, dan $K$. pneumoniae (semuanya dengan $\mathrm{p}>0,05)$ pada kelompok ASI maupun non-ASI.

\section{Pembahasan}

Kemajuan perawatan obsteri dan neonatal meningkatkan angka bertahan hidup bayi kecil dan imatur sehingga lebih banyak bayi berat lahir sangat rendah (<1500 gram) yang dapat hidup. Bayi imatur merupakan populasi yang sangat berisiko mengalami NEC. Studi epidemiologi oleh Lin $\mathrm{dkk}^{20}$ menyebutkan bahwa angka kejadian NEC berhubungan terbalik dengan berat lahir dan usia gestasi. Penyakit NEC terjadi pada $11,5 \%$ bayi dengan berat (401-750) gram, $9 \%$ (751-1000) gram, 6\% (1001-1250) gram, dan 4\% (1251-1500) gram.

Pada penelitian kami, 15 subjek NEC merupakan bayi dengan berat lahir (1000-1499) gram, $5(<1000)$, dan 10 (1500-1999). Rerata berat lahir pada subjek NEC 1320 gram (SD 330 gram, rentang 650 -1850 gram). Median usia gestasi subjek NEC yaitu 32 minggu (27-35 minggu). Studi oleh Lin $\mathrm{dkk}^{20}$ juga menyebutkan bahwa tidak ada hubungan yang konsisten antara jenis kelamin dan penyakit NEC, tetapi bayi laki-laki dengan berat lahir sangat rendah memiliki risiko meninggal lebih tinggi.

Didapatkan 24 subjek NEC sebelumnya telah mendapat minum berupa ASI, susu formula, gabungan ASI dan susu formula, dan 6 subjek lainnya belum mendapat minum. Enterokolitis nekrotikans sangat jarang terjadi pada neonatus yang belum mendapat minum. Penyakit NEC biasanya terjadi pada minggu kedua kehidupan setelah pemberian minum enteral diberikan. Berseth $\mathrm{dkk}^{21}$ melaporkan bahwa lebih dari 90\% kasus neonatus dengan NEC telah mendapat minum sebelumnya. Namun, Berman $\mathrm{dkk}^{22}$ melaporkan bahwa terjadi peningkatan jumlah kasus NEC pada bayi yang belum pernah mendapatkan minum. Juga terdapat laporan bahwa bayi usia gestasi 23-28 minggu mengalami NEC saat usia beberapa minggu kehidupan dan hal ini terjadi lama setelah pemberian minum diberikan. ${ }^{23}$ Median usia saat subjek mengalami NEC 13,5 hari setelah lahir (rentang 5-64 hari).
Kecenderungan dominasi Klebsiella pneumoniae pada subjek NEC menunjukkan adanya kolonisasi abnormal saluran cerna dan ketidakseimbangan antara kolonisasi mikroflora patogen dan normal. Komponen liposakarida Klebsiella pneumoniae dapat menyebabkan kerusakan sel epitel saluran cerna dan mengganggu hemodinamik splanchic. Produk mikroflora normal saluran cerna berupa asam lemak rantai pendek, asetat, propionat, dan butirat yang diperlukan untuk diferensiasi sel-sel epitel intestinal juga terganggu dengan adanya mikroflora patogen ini. Klebsiella pneumoniae merupakan salah satu mikroflora patogen penyebab infeksi nosokomial dan dapat tumbuh leluasa pada pasien imunokompromais termasuk NKB. ${ }^{24,25}$

Kecenderungan dominasi Bifidobacterium sp. pada subjek tanpa NEC menunjukkan bahwa mikroflora ini dapat mengatur keseimbangan antara mikroflora komensal dan patogen pada saluran cerna sehingga dapat mencegah NEC. Bifidobacterium merupakan kelompok utama bakteri sakarolisis di usus besar, sekitar 25\% ada pada kolon dewasa, dan 95\% pada bayi baru lahir yang diberi ASI. Flora normal ini dapat memproduksi asam kuat sebagai hasil akhir metabolisme seperti asetat dan laktat yang dapat menurunkan $\mathrm{pH}$ lingkungan lokal, serta menghasilkan efek antibiotik. Bifidobacterium juga menghasilkan produk-produk enzimatik yang dapat memperkuat integritas sawar intestinal sehingga dapat mencegah translokasi bakteri patogen. Bifidobacterium secara in vitro dapat menghambat bakteri anaerob seperti Clostridium, Bacteroides, Pseudomonas, Staphylococcus, Streptococcus, Enterobacter, dan Salmonella. ${ }^{10}$

Pada bayi yang lahir bedah kaisar terjadi penundaan dan pola abnormal kualitatif kolonisasi usus. Pola abnormal ini memengaruhi perkembangan saluran cerna dan berisiko tinggi mengalami infeksi gastrointestinal seperti NEC. Hasil penelitian kami tidak menunjukkan perbedaan proporsi mikroflora Bifidobacterium sp., K. pneumoniae, B. lactis, Lactobacillus sp., L. acidophilus, E. coli, maupun $C$. diffcile pada subjek NEC yang lahir spontan maupun bedah kaisar. Proporsi mikroflora dengan rerata 27,7\% pada subjek NEC yang lahir spontan dan 12, 5\% lahir bedah kaisar juga tidak berbeda.

Walaupun tidak menunjukkan perbedaan, terdapat kecenderungan proporsi mikroflora Bifidobacterium sp. yang lebih besar pada subjek yang lahir per vaginam. Hal tersebut sesuai dengan penelitian Penders $\mathrm{dkk}^{14}$ yang melaporkan bahwa bayi yang lahir dengan 
bedah kaisar menunjukkan jumlah Bifidobacterium lebih sedikit dibanding bayi yang lahir per vaginam. Kolonisasi saluran cerna dimulai saat bayi dilahirkan melewati vagina ibu dan bakteri fekal selama proses persalinan. ${ }^{26}$ Bakteri anaerob fakultatif dengan predominan Enterobacteriaceae, Entrococci, Streptoccoci, dan Staphylococci merupakan bakteri awal yang berkolonisasi pada saluran cerna bayi dengan jumlah $10^{8}-10^{9} \mathrm{sel} / \mathrm{g}$ tinja dalam beberapa hari setelah lahir. Kemudian diikuti dengan kolonisasi Clostridia, Bacteroides, dan Bifidobacterium dengan dominasi Bifidobacterium dalam beberapa hari setelahnya. ${ }^{13}$

Hasil penelitian kami menunjukkan bahwa pada subjek NEC tidak terdapat perbedaan proporsi mikroflora Bifidobacterium sp., B. lactis, Lactobacillussp., L. acidophilus, E. coli, C. difficile, dan K. Pneumoniae. Pada kelompok lama pemakaian antibiotik $\leq 1$ minggu, $>1$ minggu. Walaupun tidak menunjukkan perbedaan, terdapat juga kecenderungan penurunan proporsi mikroflora Bifidobacterium sp. dan peningkatan $K$. pneumoniae pada lama pemberian antibiotik $>1$ minggu. Hal tersebut menunjukkan bahwa penggunaan antibiotik secara ekstensif dapat mengganggu mikroflora normal saluran cerna, mengganggu keanekaragaman alamiah kolonisasi mikroflora, dan meningkatkan risiko bakteri tumbuh lampau. ${ }^{4,6}$

Pada subjek NEC tidak terdapat perbedaan proporsi mikroflora, Bifidobacterium sp., B. lactis, Lactobacillus sp., L.acidophilus, E. coli, C. difficile, dan K. pneumoniae pada kelompok ASI maupun Non-ASI. Walaupun tidak menunjukkan perbedaan, terdapat kecenderungan proporsi mikroflora Bifidobacterium sp.lebih besar pada subjek yang mendapat ASI. Pemberian ASI pada neonatus baru lahir dapat menstimulasi mikroflora saluran cerna yang didominasi Bifidobacteria, sedangkan susu formula dapat meningkatkan keragaman mikroflora yang didominasi oleh Enterobacteriaceae, Bacteroides, dan Clostridia dengan jumlah Bifidobacteria yang lebih sedikit. ${ }^{4,6}$ Air susu ibu mengandung laktosa, whey, kasein, dan bermacam-macam oligosakarida yang dapat memengaruhi pertumbuhan mikroflora. Air susu ibu juga terdiri atas komponen bioaktif seperti IgA, laktoferin, $\beta$-laktoglobulin, dan $\alpha$-laktalbumin yang secara langsung maupun tidak langsung dapat memengaruhi kolonisasi mikroflora. ${ }^{4}$

Keterbatasan penelitian kami yaitu hanya memeriksa 7 mikroflora (B.lactis, L. acidophilus, Bifidobacteriumsp., Lactobacillus sp..E. coli, C.difficile, dan K.pneumoniae). Pada keseluruhan subjek, proporsi ketujuh mikroflora tersebut terhadap total mikroflora yang terdeteksi pada sampel tinja berkisar dari 4,1\% hingga 98,6\% sehingga diperlukan penelitian lain yang memeriksa lebih banyak jenis mikroflora. Desain paling ideal untuk menilai faktor risiko yang memengaruhi kolonisasi mikroflora saluran cerna pada NKB dengan NEC adalah kohort prospektif yang subjeknya diikuti sejak lahir sampai mengalami NEC. Pemeriksaan tinja yang dilakukan sebaiknya berkala, tidak hanya saat mengalami NEC, sehingga bias diketahui perubahan kolonisasi mikroflora saluran cerna.

\section{Kesimpulan}

$K$. pneumoniae memiliki proporsi terbesar pada subjek NEC sedang Bifidobacterium sp. memiliki proporsi terbesar pada subjek tanpa NEC. Cara persalinan, lama pemakaian antibiotik, dan tipe nutrisi secara statistik tidak memengaruhi proporsi kolonisasi mikroflora saluran cerna subjek NEC.

\section{Daftar pustaka}

1. Stoll BJ, Hansen NI, Bell EF. Neonatal outcomes of extremely preterm infants from the NICHD neonatal research network. Pediatrics 2010;126:443-56.

2. Beeby PJ, Jeffery H. Risk factors for necrotizing enterocolitis: the influence of gestasional age. Arch Dis Child 1992:67:432-5.

3. Leviton A, Damman O, Engelke S. The clustering of disorders in infants born before the 28th week of gestation. Acta Pediatr 2010;99:1795-800.

4. Lin PW, Nasr TR, Stoll BJ. Necrotizing enterocolitis: recent scientific advances in patophysiology and prevention. Semin Perinatol 2008;32:70-82.

5. Wendelboe AM, Smelser C, Lucero CA, McDonald LC. Cluster of necrotizing enterocolitis in a neonatal intensive care unit. Am J Infect control 2010;38:144-8.

6. Hunter CJ, Upperman JS, Ford HR, Camerini V. Understanding the susceptibility of the premature infants to necrotizing enterocolitis. Pediatr Res 2008;63:11723.

7. Wang Y, Hoenig JD, Malin KJ, Qamar A, Petrof EO, Sun J, dkk. 16S rRNA gene based analysis of fecal microbiota for preterm infants with and without necrotizing enterocolitis. ISME J 2009;3:944-54.

8. Morgan JA, Young L, McGuire W. Pathogenesis and 
prevention of necrotizing enterocolitis. Curr Opin Inf Dis 2011;24:183-9.

9. Boyd CA, Quigley MA, Brocklehurst P. Donor breast milk versus infant formula for preterm infants: systematic review and meta-analysis. Arch Dis Child Fetal Neonatal 2007;92:169-75.

10. Butel MJ, Suau A, Campeotto F, Magne F. Conditions of bifidobacterial colonization in preterm infants. J Pediatr Gastroenterol Nutr 2007:44:577-82.

11. Harmsen H, Wildeboer-Veloo A, Raangs G. Analysis of intestinal flora development in breast-fed and formula-fed infants by using molecular identification and detection methods. J Pediatr Gastroenterol Nutr 2000;30:61-7.

12. Penders J, Vink C, Driessen C, London N, Thijs C, Stobberingh EE. Quantification of Bifidobacterium sp., Escherichia coli and Clostridium difficile in faecal samples of breast-fed and formula-fed infants by realtime PCR. FEMS Microbiol Letters 2005;243:141-7.

13. Thompson-Chagoyan OC, Maldonado J, Gil A. Colonization and impact of disease and other factors on intestinal microbiota. Dig Dig Sci 2007;52:2069-77.

14. Penders J. Factors influencing the composition of the intestinal microbiota in early infancy. Pediatrics 2006;118:511-21.

15. Hall M, Cole C, Smith S. Factor influencing the presence of faecal Lactobacilli in early infancy. Arch Dis Child 1990;65:185-88.

16. Gewolb IH, Schwalbe RS, Taciak VL, Harrison TS, Panigrahi P. Stool microflora in extremely low birthweight infants. Arch Dis Child Fetal Neonatal
1999;80:167-73.

17. Deshpande G, Rao S, Patole S, Bulsara M. Updated meta-analysis of probiotics for preventing necrotizing enterocolitis in preterm neonates. Pediatrics. 2010;125: 921-30.

18. Bell MJ. Neonatal necrotizing enterocolitis. N Engl J Med 1978;298:281-2.

19. Ballard JL, Khoury JC, Wedig K. New Ballard score, expanded to include extremely premature infants. J Pediatr 1991;119:417-23.

20. Lin PW, Stoll BJ. Necrotizing enterocolitis. Lancet. 2006;368:1271-83.

21. Berseth CL. Feeding strategies and necrotizing enterocolitis. Curr Opin Pediatr 2005;17:170-3.

22. Berman L, Moss RL. Necrotizing enterocolitis: an update. Semin Neonatol 2011;16:145-50.

23. Moss RL, Kalish LA, Duggan C. Clinical parameters do not adequately predict outcome in necrotizing enterocolitis: a multi-institusional study. J Perinatol 2008;28:665-774.

24. Schwiertz A, Gruhl B, Lobnitz M, Michel P, Radke M, Blaut M. Development of the intestinal bacterial composition in hospitalized preterm infants in comparison with breastfed, fullterm infants. Pediatr Research 2003;3:393-9.

25. Podschun R, Ullman U. Klebsiella spp. as nosocomialpathogens: epidemiology, taxonomy, typingmethods, and pathogenicityfactors. Clin Microbiol Rev 1998;11:589-603.

26. Stark P, Lee A. The microbial ecology of the large bowel of breast-fed and formula-fed infants during the first year of life. J Med Microbiol 1982;15:189-203. 